\title{
Pensamento filosófico da Desconstrução e Teoria da Interpretação
}

\author{
Maria Antonieta Jordão de Oliveira Borba ${ }^{1}$
}

Resumo: Este artigo constitui uma reflexão sobre o pensamento da Desconstrução, de Michel Foucault e de Jacques Derrida, objetivando descrever de que modo suas ideias foram compreendidas por Silviano Santiago, quando este examinou a literatura e a cultura brasileiras nos anos setenta e oitenta. Os conceitos criados por Silviano Santiago são capazes de revelar outra perspectiva de interpretação à medida que faz uma crítica às teorias metafísicas do Ocidente.

Palavras-chave: Desconstrução. Interpretação. Cultura e literatura brasileiras.

No campo das ciências humanas e sociais, a Desconstrução francesa reveste-se de significativa relevância por ter fundado os pressupostos de uma nova perspectiva de estudos das relações do sujeito com o discurso, a história, a cultura. Tendo surgido na década de 70 , permanece como referência profícua para subsidiar pesquisas sobre movimento de margem $^{2}$, desde que revelou a fragilidade da metafísica como hierarquizadora da noção de centro e estruturante do pensamento binário. Sabe-se ainda que, comprometidos com a ruptura epistemológica da Desconstrução, encontramos dois dos mais importantes pensadores do século XX, Michel Foucault e Jacques Derrida. Repensando a história das ideias e revisando a história da filosofia, os filósofos efetuaram um corte no corpo do Estruturalismo, quando puseram em xeque a "principalidade" dos princípios metafísicos, abalando noções decorrentes do legado platônico como continuidade, unidade do sujeito, valor de autoria, paradigma opositivo, profundidade discursiva, verdade do discurso etc.

Semelhante a Foucault e Derrida, o crítico, escritor e ensaísta brasileiro Silviano Santiago inaugurou um novo ângulo de literatura comparada, quando rasurou os protocolos de leitura vigentes quanto à avaliação crítica entre culturas colonizadas e colonizadoras. Através de ensaios publicados desde a década de 70, Silviano vem apresentando uma compreensão diferenciada de interpretação, tendo deixado como marco de sua literatura comparada a positividade da diferença. A partir desse cenário, o artigo deverá retomar alguns dos

\footnotetext{
1 Maria Antonieta Jordão de Oliveira Borba é professora associada do programa de pós-graduação e graduação em Letras da UERJ. Publicou os livros Teoria do efeito estético (Niterói, RJ: EDUFF, 2003); Tópicos de Teoria para a investigação do discurso literário (Rio de Janeiro: 7 Letras, 2004); Sentidos de interpretação. (Rio de Janeiro: Editora do SNEL, 2006). E-mail: majordao@gbl.com.br.

${ }^{2}$ Denominamos movimento de margem formas de manifestação não reconhecidas, em função do tempo, lugar e espaço em que surgem. Num sentido mais amplo, diz respeito tanto àquelas das culturas que foram colonizadas quanto de outras que, surgindo na periferia dos centros urbanos, permanecem somente com o aval de um determinado grupo ou classe social.
} 
principais momentos das reflexões dos franceses, a fim de verificar, nessa base conceitual, de que modo Silviano pôde construir uma matriz teórica cujos pressupostos orientam interpretações capazes de revelar contribuição entre obras de culturas diferentes, ao invés de postularem a dívida de uma em relação à outra.

Várias foram as noções desenvolvidas por Michel Foucault e Jacques Derrida que, remetendo diretamente para a cadeia sintagmática, caracterizaram o discurso pela valorização da superfície e por uma atividade específica de interpretação. Correlatos a esses conceitos, agrupam-se outros como sujeito, fragmentação, descontinuidade, jogo, força, traço, escritura, diferença, indecidibilidade, descentramento. Tais estratégias nocionais, por sua vez, só puderam ser desenvolvidas, em função dos cortes operados por Nietzsche, Freud e Marx, quando irrompem na modernidade. Foi com base nas reflexões desses filósofos que Foucault e Derrida desenvolveram campos conceituais próprios, respectivamente sobre a história das ideias (na proposição da arqueologia do saber e da genealogia do poder) e sobre o fono-logocentrismo ${ }^{3}$ da metafísica ocidental (na proposição da gramatologia).

Das variantes correlatas ao conceito de interpretação, duas das mais significativas em Nietzsche, Freud e Marx referem-se à crítica da profundidade do discurso e à crítica da verdade. É o que escreve Foucault (FOUCAULT, s/d) sobre o pensamento de Marx, ao lembrar, por exemplo, a platitude pela qual nomeou os estudos profundos sobre a moeda, o valor e o capital. A negação do palimpsesto ${ }^{4}$ evidencia-se também no momento em que, interessado pelas relações de produção, Marx entendeu-as como se oferecendo à interpretação em suas próprias emergências, o que fez com que abandonasse o trajeto formado pela história desse objeto. Em Nietzsche, a revisão da profundidade ocorreu junto com a crítica da crença no abismo da consciência, terminando por caracterizá-la como um engenho dos filósofos. Em suas obras, Nietzsche negou os conceitos de ser e de verdade que percorreram a metafísica, ao lembrar que o caminho em direção aos solos profundos, por obrigar a retirada da terra da superfície, só faria revelar a exterioridade ou a superfície da profundidade ${ }^{5}$. Do mesmo modo que Nietzsche e Marx, as reflexões de Freud apresentaram sintomas contrários à concepção de que o conhecimento ocupava um lugar distante daquele pelo qual um objeto se oferece à interpretação. O inconsciente como portador de uma

\footnotetext{
${ }^{3}$ Fono-logo-centrismo remete para a crença de que a escrita é inseparável da fala, que se confunde com o ser em presença no discurso.

${ }^{4}$ Conceito que remete para a camada profunda do discurso.

5 A cebola que, descascada, nada contém, revelou-se como boa metáfora para ilustrar a crítica à ideia de profundeza. De nada adianta retirar as cascas porque é ilusão pensar que será encontrado um núcleo ao final. Do mesmo modo, o discurso não contém uma verdade, uma origem, em deus, um telos, no aprofundamento das camadas superficiais.
} 
gramática estranha ao homem, acrescido da ideia da submissão que impunha à linguagem, criou um impasse à investigação do discurso como condição de verdade. Os pensamentos de Nietzsche, Freud e Marx operaram, portanto, uma ruptura com o princípio de que interpretar exige escavar as camadas do discurso. Para eles, quanto mais a interpretação avançasse para o suposto encontro com a verdade, mais se aproximaria da morte. Implícito ao gesto nessa direção, permaneceria o falso pressuposto de que a investigação do símbolo conduziria à coisa em si, como se este símbolo vivesse uma origem que lhe pertencesse ou fosse a própria coisa que apenas simboliza:

A morte da interpretação é o crer que há símbolos que existem primariamente, realmente, como marcas correntes, pertinentes e sistemáticas. A vida da interpretação, pelo contrário, é o crer que não há mais do que interpretações (FOUCAULT, s/d, p. 21).

A leitura de Nietzsche, Freud e Marx realizada por Michel Foucault permitiu-lhe efetivar um novo olhar para a história em suas relações com o saber e o poder, o que de início se fez através de seu projeto arqueológico e, posteriormente, com o projeto genealógico. Praticado de modo explícito em As palavras e as coisas (FOUCAULT, 1966) e aprofundado em A arqueologia do saber (FOUCAULT, 1972), o projeto arqueológico revestiu-se de caráter inaugural, quando Foucault se posicionou conceitualmente contrário à existência de determinadas unidades fixas a regularem as produções discursivas. Para ele, os discursos deveriam ser analisados não mais por unidades que os classificam em função do objeto, da forma de enunciação, dos conceitos, dos temas, mas pela própria dispersão em que se encontram. Objeto, conceito, tema, enunciação deixaram de constituir regras de formação do discurso porque, para o filósofo, caracterizam-se como dados que são regulados no aparecimento das produções discursivas. Os vários e dispersos enunciados, as perspectivas e os fenômenos da sociedade são elementos responsáveis para que o objeto se constitua como tal. São esses fenômenos que estabelecem as condições de possibilidade de emergência discursiva. Referindo-se ao discurso psiquiátrico e ao objeto dessa formação discursiva, por exemplo, Foucault escreve o seguinte:

Generalizemos: o discurso psiquiátrico, no século XIX, caracteriza-se não por objetos privilegiados, mas pela maneira pela qual forma seus objetos, de resto muito dispersos aparecem. Essa formação é assegurada por um conjunto de relações estabelecidas entre instâncias de emergência, de delimitação e de especificação. Dir-se-á, pois, que uma formação discursiva se define (pelo menos quanto a seus objetos) caso se possa estabelecer 
semelhante conjunto, podendo mostrar como qualquer objeto do discurso aí encontra seu lugar e sua lei de aparecimento (FOUCAULT, 1972, p. 59).

As análises arqueológicas realizadas por Foucault em História da loucura (FOUCAULT, 2007) e Nascimento da clínica (FOUCAULT, 2011) configuraram-se como espécie de práxis do que havia teorizado sobre relação entre produções discursivas e acontecimentos. Foi aí que o autor acentuou a necessidade de articulação entre regras de formação discursiva a fatores das mais distintas ordens, como os que os que ocorrem nos segmentos político, social, econômico. Agindo no campo da epistemologia, Foucault compreendeu a história das ideias não como história da evolução da racionalidade, mas como relação que uma ideia estabelece com outra, uma relação de ruptura entre epistémes. Neste sentido, seu interesse não foi definir o que significa tal discurso, mas indagar por que uma epistéme possibilitou o surgimento de um discurso, ou ainda, por que e como um objeto pode aparecer. Assim, a caracterização dos solos epistemológicos vincula-se à determinação de regras de aparecimento de discursos, o que implica analisar as condições de possibilidade de suas irrupções. A história arqueológica foucaultiana propõe-se a interpretar estruturas que percorrem os períodos, através da investigação de acontecimentos que, em suas dispersões, foram deixados para segundo plano pela história tradicional. Ao propor a relação de ruptura entre as ideias, Foucault apontou para a possibilidade de se compreender sua formação pela descontinuidade, o que fez com que deixasse de ter sentido a tradicional classificação linear dos períodos. Assim, a interpretação de um determinado objeto (doença mental, sexualidade, representação pictórica) supõe que esse objeto participa de uma história que lhe é própria, independente do percurso que deixou marcado.

Todo o movimento provocado pela reflexão foucaultiana em torno de descontinuidade, sujeito fragmentado, solo epistemológico se avizinha de aspectos correlatos a uma concepção de interpretação, que exigiu o exame crítico de noções como origem, consciência do sujeito, profundidade. Conforme observou Foucault na leitura de Nietzsche, se não há nada anterior ao signo, tudo já é interpretação e esta tarefa nada mais significa do que o estabelecimento de um jogo inacabado e infinito:

Se a interpretação não se pode nunca acabar, isto quer simplesmente significar que não há nada a interpretar, porque no fundo tudo é interpretação, cada símbolo é em si mesmo não a coisa que se oferece à interpretação, mas a interpretação de outros símbolos (FOUCAULT, s/d, p. 16). 
O propósito de analisar a interpretação em meio ao pensamento da Desconstrução traz necessariamente para debate as ideias de Jacques Derrida, pelo mesmo nível de relevância atribuído às de Michel Foucault. Derrida pôs em crise tanto a atividade estruturalista a que se vinculou, quanto os pressupostos de um quadro mais amplo, o da filosofia ocidental. Marcando as bases fono-logo-cêntricas ${ }^{6}$ que sustentaram o pensamento te(le)ológico ${ }^{7}$, abalou uma série de conceitos aí dominantes, sem contudo simplesmente virar a página da filosofia. Sua Gramatologia (DERRIDA, 1973) repensou os conceitos da metafísica, examinando-os a partir de um gesto que consistiu em ler os filósofos de uma "certa maneira". Para ele, isso significava dizer que só seria possível criticar a metafísica usando a mesma escrita de que ela se utiliza, até porque a gramatologia por ele reivindicada não se encontra em nenhuma língua, mas na noção escritura $^{8}$. Por essa determinação, suas ideias são configuradas como o pensamento das margens da filosofia. Consiste numa escrita simultaneamente comprometida e afastada da filosofia, uma escrita que emprega o mesmo discurso que visa rasurar: "Não tem nenhum sentido abandonar os conceitos da metafísica para abalar a metafísica; não dispomos de nenhuma linguagem - de nenhuma sintaxe e de nenhum léxico - que seja estranha a essa história” (DERRIDA, 1971, p. 233).

Os caracteres finalista e religioso que orientam as bases te(le)ológicas da metafísica giram em torno da noção de centro e respondem pelas denominações de arquê / telos, deus, recebidas por esse centro. Entretanto, por se referir a um ponto da estrutura do discurso, o centro pode, indiscriminadamente, ser denominado por origem, consciência, arquê, telos, deus, homem, todos esses designando a invariante de uma presença, ou significado transcendental. Sabe-se, também, que a metafísica se edificou pelo pré-conceito de que a phoné, inseparável do logos, confundia-se com a presença do ser. Diante dessas caracterizações, Derrida soube bem observar que a crença numa escrita de natureza puramente fonética [fono-logo-centrismo] encontra suporte no pensamento de Platão, segundo o qual a verdade, ligada à Ideia, só podia ser buscada com a presença daquele que fala. Configurada nessa ordem, o pensamento ocidental sempre afirmou o homem, "sonhou a presença plena, o fundamento tranqüilizador, a origem e o fim do jogo" (DERRIDA, 1971, p. 249). Daí o gesto de a metafísica querer continuamente estancar a mobilidade própria de qualquer estrutura, sua estruturalidade, quando era atribuído ao discurso um télos, ponto de presença ou origem. Foi

\footnotetext{
${ }^{6} \mathrm{O}$ pensamento baseado na natureza fonética (fono), verbal (logo), etnocêntrico ou de cultura de referência (centrismo).

7 Te(le)ológico. Como a escrita sinaliza, a palavra condensa, nela mesma, o telos (caráter finalista do pensamento) e o teológico (Deus, homem, origem, fim).

${ }^{8}$ Escritura é um conceito anterior à escrita. Esta distingue o significado que vai ser ocupado na cadeia. Aquela, tal como um pharmakon, não o faz. Contém, ao mesmo tempo, o remédio e o veneno.
} 
assim que Derrida explicou o fato de o significado ter sido sempre privilegiado, o que implicou, por sua vez, o recalcamento da própria força do significante.

Na revisão do Estruturalismo feita por Derrida, somos levados primeiramente a observar por que o pensamento das ciências humanas e sociais se fixou na ideia de centro e quais foram as consequências do pensamento binário. Era comum aos procedimentos de base analítica o olhar colado nos elementos opositivos, por se pautarem na clássica oposição de Platão entre o sensível e o inteligível. Por essa via, a metafísica armou suas oposições, separou e hierarquizou fala e escrita, privilegiando aquela e rebaixando esta. À fala estiveram relacionados o inteligível, a essência, o verdadeiro, o dentro; à escrita, o sensível, a aparência, of falso, o fora. Derrida argumentou que, se o espaçamento entre os signos revelava a impossibilidade de uma escrita puramente fonética, era preciso pensar essa escrita como escritura. A escritura, por ser anterior à escrita, é traço mnemônico ${ }^{9}$, anterior à linguagem, anterior ao sujeito; portanto, não pode ser nem representação de imagem nem da fala, nem "depende de nenhuma plenitude sensível, audível ou visível, fônica ou gráfica" (SANTIAGO, 1976, p. 30). Sendo anterior a todas as oposições (inteligível/sensível; essência/aparência; verdadeiro/falso), a escritura é uma différance, um pharmakon ${ }^{10}$, com toda a indecidibilidade a suscitar um jogo entre seus significantes. A escritura nega a primariedade da fala, mata o pai, configurando-se por um jogo indecidivel, um pharmakon, tal como aparece no mito do nascimento da escrita, remédio e veneno, simultaneamente como duas forças.

$\mathrm{Na}$ différ $\underline{A}$ nce, os signos não se encontram distinguidos em seus significados. Para melhor ilustrar essa anterioridade, diríamos que o texto seria comparável a um palco, em que há o proscênio e o fundo da cena. Somente no momento em que se escreve, fica determinado qual significante ocupa o proscênio, o que permite melhor compreender por que Derrida afirmou o recalcamento do significado. O fenômeno pode ser ainda exemplificado através do

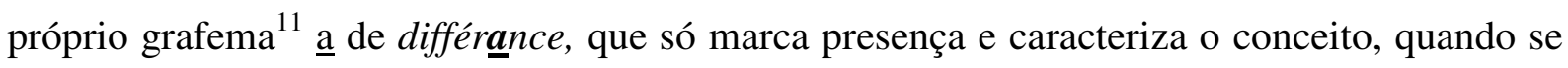

\footnotetext{
${ }^{9}$ Quando Derrida pesquisou as reflexões de Freud sobre o aparelho psíquico, pôde verificar que, diferentemente dos neurônios da percepção pelos quais tudo passa sem ser retido, os neurônios da memória oferecem grades de contato, resistência, o que faz com que a inscrição do traço [recalque] no inconsciente se dê por violência a tal resistência. No entanto, como o significado do traço só se dá a posteriori, a interpretação desse significado vem sempre em atraso. Nesse sentido, o traço, ou a escritura é anterior ao sujeito, o que permite deduzir que a escritura retira o sujeito, mata o pai no momento em que nasce. O ser está ausente da escritura.

${ }^{10}$ Pharmakon, em grego, remete, simultaneamente, para dois significados: remédio e veneno. Ver "A invenção da escrita", em Fedro (PLATÃO, 2001).

${ }^{11}$ Os grafemas constituem uma abstração formal de símbolos que convencionalmente representam um fonema ao qual damos o nome de letra, ou seja, o grafema é a ideia acerca das formas do símbolo e a letra é a materialização (representação gráfica). Os grafemas por serem unidades fundamentais permitem que reconheçamos uma dada letra escrita sob formas um tanto diversas do paradigma. Exemplos: A, a. Embora estejam grafadas diferentemente, essas duas representações são reconhecidas por meio da ideia que se tem do
} 
faz uso da língua escrita. A sonoridade da fala francesa é incapaz de distinguir a différance - a anterioridade da diferenciação - de différence, momento em que os significantes apontam para outros significados. Se a escrita tem esse poder de recalque do significado, a interpretação não poderia ser cúmplice do mesmo gesto; se assim agisse, só faria ratificar a metafísica, atitude que em nada diferiria do recalque; apenas promoveria um novo recalque. Interpretar significa fazer proliferar o próprio significante, uma atividade realizada, por exemplo, em pelo menos três propostas escritas de que temos conhecimento: Roland Barthes, interpretando a novela Sarrasine de Balzac em seu livro S/Z (BARTHES, 1970); Roberto Corrêa dos Santos, interpretando contos em seu livro Clarice Lispector (SANTOS, 1986).

Quando Derrida pensou no conceito de différance, tratou, simultaneamente, das respectivas variantes, ou seja, da escritura e da interpretação. A interpretação que trabalha com a différance ativa o pharmakon, não se decide por um significado específico do signo, deixa emergirem as forças de remédio e veneno, de bem e mal, enfim, de todas as oposições, de todas as distinções, de todas as différennces passíveis de verificação. Derrida não quis que sua interpretação se configurasse por leitura ideológica, tal qual como fez a história do sentido - o sentido te(le)ológico - pautada no centramento do discurso (crença no valor de verdade da palavra e do ser enquanto presença) - fono-logo-centrismo - e numa cultura de referência - etnocentrismo. Fazer falar a força do texto implica promover o descentramento da estrutura, isto é, não frear a mobilidade que lhe é própria, e sim ativar-lhe o próprio jogo. Para isso, Derrida propôs um conceito de interpretação que trabalhasse com as noções de jogo, diferença, indecidibilidade, escritura, ausência do ser.

Diante desse quadro, já é possível verificar de que modo Silviano Santiago se apropriou da base filosófica da Desconstrução para repensar os estudos comparatistas, o que lhe permitiu compor sua matriz teórica de interpretação. Abandonando o etnocentrismo da metafísica, a produção de nosso intelectual desde a década de 70, sinalizando para o produtivo diálogo da diferença entre literaturas e culturas em perspectiva comparada. $\mathrm{O}$ conceito permanece com sua potência, ainda que tenhamos que considerar que a trajetória de suas ideias e o conceito de diferença tenham passado por novas conceituações, em face das mudanças provocadas pelas transformações sociais com o fenômeno da globalização.

A obra de Silviano Santiago constitui a face mais visível da complexidade com que o autor compreendeu as relações entre literatura e cultura de estados pós-colonialistas. Dizer seu nome é o mesmo que se referir ao reconhecido intérprete das textualidades plasticamente

símbolo "a", isto é, por meio do grafema "a" . À medida que esta abstração é posta no papel automaticamente recebe o nome de letra, ou seja, a escrita em si. 
ligadas à tradição latino-americana. Sua inserção no campo de comparada nas décadas finais do século XX revestiu-se de um prisma específico de leitura das manifestações lítero-culturais de margem, em que o violento processo de colonização não se desvincula da imaginação criativa do artista. Trata-se de uma abordagem resultante de quem soube perceber a condição de sujeitos atravessados pelo trauma gravado na história de seus países. O artista da cultura dependente, ao mesmo tempo em que vislumbrava a tradição, trazia consigo o sentido de uma nacionalidade. Vivia um estado de contradição, contradição essa, entretanto, que não se diluía em síntese, como preveem os destinos das concepções ideológicas e contraideológicas. No aproveitamento do conceito nietzscheano de afirmação, Silviano entendeu que tanto o sentimento de raiz, quanto o apelo da forma universal atuaram como forças das subjetividades discursivas dos poetas e escritores das culturas colonizadas. Daí as manifestações desse "entre-lugar" engendrarem maior rentabilidade, quando suas estéticas fossem observadas nos aspectos que elas mesmas capacitam à interpretação: "apropriação", "transgressão" e "rearticulação" da literatura, seja entre o "discurso latino-americano" e a literatura canônica do Ocidente, seja entre as intertextualidades produzidas em um mesmo país ${ }^{12}$.

No livro que Silviano publicou em 2004, O cosmopolitismo do pobre (SANTIAGO, 2004), a Desconstrução de Michel Foucault e Jacques Derrida dá sinais da vitalidade de pressupostos, quando o autor nos lembra que os movimentos identitários de cultura buscam inventividades, sem se ausentarem do que as formas estrangeiras paralelamente se propõem a realizar. Já nas páginas iniciais do ensaio "Atração do Mundo", fica evidente o lastro francês que perpassa a interpretação das mudanças dos modelos estéticos. Através da metáfora de "espectador do século", presente no texto de Nabuco, Silviano vai desconstruindo, por um lado, os que sublinharam as mazelas de um Alencar em busca de mitos da identidade nacional e, por outro, explorando as lembranças de um narrador que, na velhice, confessa o fascínio que sempre sentiu pela geografia e pelo espetáculo cultural da tradição europeia. Por essa trajetória desestabilizadora de questões sobre nacionalidade, Silviano chega ao final do capítulo, lembrando-nos de um curioso fenômeno da sociedade contemporânea. Hoje somos testemunhas de duas tendências de manifestações artísticas que, por propósitos diferenciados, têm se voltado para a expressão de novas formas de identidade cultural. Por um lado, percebem-se certos "casulos" no "cotidiano de grandes cidades" (SANTIAGO, 2004, p. 40) "pipocando" aqui e ali e, apesar da dispersão, são capazes de se comunicar diretamente com grupos estrangeiros semelhantes, firmando "alianças cosmopolitas" horizontalmente

\footnotetext{
${ }^{12}$ Acrescento esta última possibilidade pelas anotações de aulas com Silviano Santiago, conforme discutirei adiante, quando estiver tratando da leitura que faz do verso "Minha terra tem palmares" de Oswald de Andrade.
} 
dialógicas, ou seja, sem dependerem da verticalidade própria de quem vai pedir o aval do Estado. Por outro lado, existem grupos que, "antipáticos” à globalização, se organizam em torno da defesa da preservação das tradições regionais, como forma de reagirem ao que denominam "mesmismo globalizado". Ambos, porém, constituem movimentos de identidade que estão "aquém e além do nacional", e que por isso se distanciam do modelo da tradição imposta pelas elites brancas, patriarcais, etnocêntricas.

É essa dicção do discurso de Silviano Santiago que percorre as obras da segunda metade do século XX e que ainda respondem, pelo menos quanto ao conceito de diferença, pelas interpretações que produz. Por volta dos anos 70, em seu retorno ao Brasil depois de atuar na França, encontrou no meio acadêmico um clima propício para a expansão de uma proposta de Literatura comparada, que rompeu com as análises baseadas no paradigma norteador de “cópia”, “imitação", "fonte”, “influência”, “atraso”, "repetição”. Sua nova grade conceitual serviu-lhe para que interpretasse as relações entre culturas, objetivando discorrer sobre o modo pelo qual as obras produzidas na margem apresentavam particularidades capazes de dialogar produtivamente com as da tradição. Criadas em condição de dependência, no sentido de serem construídas em países cujo estágio sócio-econômico revelavam um gap em relação às das colônias, as expressões líteroculturais da América latina demandavam que o intérprete ultrapassasse os parcos limites da "imitação", a fim de explorá-las em suas mais abrangentes potencialidades. Para isso, era essencial que a interpretação observasse a diferença, principalmente quando essas marcas se inscreviam no interior das semelhanças, tendo em vista a estratégia do artista que se apropria do "já-dito" para nele interferir através de criações artísticas. Diferente das análises formais voltadas para a construção de um sentido, ou para o fator "influência" na capacidade de um escritor bem escrever grandes obras, a matriz de Santiago promoveu uma ampla revisão das proposições estruturalistas de Barthes, LéviStrauss e Gerard Gennete. Subjacentes à sua teoria, percorrem vários conceitos do pensamento filosófico francês da Desconstrução, dentre eles, o de descontinuidade histórica, de Michel Foucault (FOUCAULT, 1972), e o de escritura (ou pharmakon, différance, traço), de Jacques Derrida (DERRIDA, 1973). Trata-se de noções fundamentais para sua concepção de interpretação, sendo que o próprio espaço de sala de aula, como veremos a seguir, se caracterizou para nós como um caminho instigante do que chegava pela divulgação de suas obras.

"A semente ou a impossibilidade de se falar da origem" é o título de um curso ministrado por Silviano Santiago na PUC-RIO da década de 70 que ilustra a peculiaridade da concepção de interpretação pela qual abordou os primeiros textos escritos no Brasil e o tema 
da colonização portuguesa. Trata-se de uma perspectiva teórica que rompeu com a ideia de construção de identidade vinculada ao etnocentrismo ou às marcas remotas do ideal vigente no já decantado romantismo. Recusando o coro do nacionalismo utópico, distante da lamúria na denúncia de perdas de nossas raízes, afastando-se do discurso oficial da História, as reflexões de Santiago revelavam estreita aliança com a Etnologia e a Filosofia. Era pelo pressuposto da Desconstrução francesa que ele se aproximava de uma espécie de filosofia do "sim", no sentido nietzscheano do termo, propondo uma interpretação segundo a qual os signos do discurso eram afirmados pelos significantes de superfície, e não pela escavação das profundidades textuais. Suas leituras iam ao encontro da positividade da diferença, o que implicava fazer falar o pharmakon ${ }^{13}$, a variante de escritura (DERRIDA, 1973), suscitando verificar os significados de que se reveste o termo "semente" na pregação jesuítica.

Remetendo tanto para o sentido metafórico - o sêmen da palavra de Deus -, quanto para o literal do "em se plantando tudo dá", a leitura da "semente" de escritos em terra firme desmascarava a imagem de cordialidade, que, volta e meia, era passada a limpo pelos manuais da História, quando se descrevia o encontro entre portugueses e indígenas. Junto ao pensamento francês, desta vez mais próximo de Derrida, foi possível verificar, na própria escritura dos colonizadores, a violência do processo expansionista do Império. Pela Literatura comparada de Silviano, a resistência do outro (indígena) podia ser resgatada na palavra do mesmo (português), estivesse ela compondo os poemas de José de Anchieta, a Carta de Pero Vaz de Caminha, ou mesmo a correspondência entre Manuel da Nóbrega e o Rei de Portugal. Para isso, seria preciso relativizar o sentido metafórico de "semente" nos textos da catequese, deixar de lado o complemento da tradição analítica e pensar a "semente" pelo suplemento, o que implicava fazer emergir a potência dos significados literal e metafórico. Se o complemento sempre remeteu para a ideia de totalidade da metafísica, o suplemento da interpretação santiago-derridiana pôde dizer do acréscimo semântico que vem se alojar ao significante disseminado na escritura jesuítica. Pelas variantes nocionais do pharmakon, sua interpretação fazia entrar em ebulição aquilo que, na escritura do mesmo, esteve sempre silenciado pelo discurso da tradição, comprometido que se via com a linearidade dos acontecimentos e com a visão do colonizador. Movimentar o texto português significava,

\footnotetext{
${ }^{13}$ A metáfora do pharmakon com que trabalha Derrida permite a ilustração da atividade interpretativa que não se decide por um significado específico do signo, pois, contrariamente, ao trabalhar com a différance, impulsiona a força do significante. Referindo-se simultaneamente para "remédio" e "veneno", o pharmakon é essa différance, o momento em que os diferentes significados se encontram nele, pharmakon, potencialmente presentes. A interpretação que se baseia nos pressupostos derridianos não apaga nenhum dos significados. Deixa, pelo contrário, emergirem as forças de todas as oposições, de todas as distinções, de todas as différences passíveis de verificação, quando se trabalha a différance.
} 
portanto, abalar a estrutura centrada, permitir que a estruturalidade da estrutura entrasse no jogo da linguagem, conforme pensou Derrida (DERRIDA, 1971, p. 230). Além da recusa em estabelecer qualquer pacto com a ficção criada pela História, o leitor da cultura só poderia se opor ao paradigma binário do primeiro estruturalismo, desprendendo-se da análise, pela qual somente os elementos em oposição eram destacados do discurso para comporem o eixo de seleção. O objetivo passou a ser outro: levantar todas as possibilidades semânticas, na desconfiança do possível "ou” alternativo que compôs a frase de seu curso na universidade ${ }^{14}$. Foi por aí que o pharmakon "semente" do campo da religiosidade (o remédio) ${ }^{15}$ poderia ser lido também pela força de um significado diferente: a violência (veneno) com que se deu a posse da terra brasileira pelo português. Impor nova crença e destruir o "atraso" da cultura autóctone constituíam, portanto, o resultado das atitudes implicadas no gérmen missionário, do qual o colonizador precisava obter frutos religiosos e progressistas para repetir, em terra estrangeira, os valores que o orientavam em seu próprio país. Curioso notar que, nessa atividade desconstrutora do recalque metafísico, também o texto do corpo foi entendido como um campo discursivo minado de dubiedades. Se as leituras missionárias, os discursos da história, as análises comparatistas sempre reiteraram a "imitação", desta vez, a verificação do modo como o indígena posava, gesticulava, se movimentava impulsionou o intérprete a um modo de leitura que punha em xeque o sentido de "cópia" compartilhado pela tradição. $\mathrm{Na}$ perspectiva que remete para o "remédio" e o "veneno", é bem possível que a teatralidade do mesmo, praticada pelo nativo no ritual português, sinalizasse para algo semelhante às experiências daqueles que viviam originariamente em Porto Rico. Nossos indígenas poderiam, nessa "imitação", estar igualmente "sequiosos em contemplar o milagre bíblico, de provar o mistério religioso em todo seu esplendor de enigma" (SANTIAGO, 1978, p. 15). Se foi por este tipo de aparente passividade contemplativa das cenas católicas que, também entre nós, os índios dispunham seus corpos, é porque, paralelamente à absorção da cultura do colonizador, convivia outra versão, a versão própria à matriz de Santiago, cujo significado diria de um momento de comoção diante do mistério. Só que a "imitação", neste caso, seria algo ligado à própria natureza de suas religiosidades e não exclusivamente à crença no catolicismo europeu, como as análises etnocêntricas supuseram.

Essa dupla possibilidade extraída do potencial de encenação do corpo ratifica-se em textos da catequese, quando se constatam as marcas de resistência que vêm habitar a escritura

\footnotetext{
${ }^{14}$ Referimo-nos ao título "A semente ou a impossibilidade de falar da origem".

15 "Remédio" e "veneno" são termos para os quais remete o pharmakon, no mito do nascimento da escrita, tematizado no diálogo entre Sócrates e Fedro, na obra Fedro, de Platão.
} 
católica. Por elas, recupera-se, nas queixas dos textos portugueses, a perseverança de nossos bárbaros em se manterem nos costumes que lhes eram naturalmente afeitos. Não era de outra ordem o fenômeno observado nos textos da catequese. As demandas dos poemas, prosas e sermões portugueses permitiam supor que, longe da máscara do rito católico, os índios conservavam a liturgia de suas crenças, nos momentos em que, terminada a festa cordial, os espaços se revestiam da familiaridade das tribos. A leitura de um trecho do "Sermão do Espírito Santo" de Padre Antonio Vieira (1975) permitiu ver, na escritura em língua portuguesa, a "dificuldade da conversão" admitida pelo próprio Vieira. Também na carta de Padre Manoel da Nóbrega (NÓBREGA, 1931) ficava clara a resistência do habitante da terra, particularmente no trecho em que o jesuíta escreve sobre a necessidade de virem para cá "muitos da Companhia", de modo que fosse possível permanecer sustentando a palavra do "Rei" e do "Senhor dos Senhores". Em ambos, percebe-se que o outro, antes silenciado pela História, passou a poder falar pela voz do português.

Várias das noções apresentadas por Silviano Santiago no curso "A semente ou a impossibilidade de se falar da origem" fazem parte do livro Uma literatura nos trópicos de 1978. No ensaio de abertura, "O entre-lugar do discurso latino-americano", o autor termina por construir uma sintaxe teórica capaz de orientar os pressupostos pelos quais são discutidos os temas dos outros dez capítulos. Em síntese, diria que as reflexões desse ensaio de Santiago decorrem de uma epistemologia dos postulados da tradição interpretativa, sinalizando para a miopia do reiterado e insuficiente dado "invisível" que aproximava (ou aproxima) as literaturas colonizadas e dominantes. Em sintonia com as noções de descontinuidade (Foucault) e diferença (Derrida), o conceito de "entre-lugar" aí se configura como uma espécie de resposta ao questionamento que o próprio autor faz sobre o conceito de "imitação", quando reflete sobre a condição de emergência dos discursos da América latina e a função do intelectual que interpreta as produções culturais de seu país. Condensando a dubiedade da literatura e do intelectual, o "entre-lugar" sinaliza para a necessária relativização da Antropologia e a ineficácia da História em dar suporte a uma visão crítica adequada sobre comparativismo, quando se trata de analisar discursos de países que passaram por processo de colonização.

Mas é na inter-relação das idéias de Uma literatura nos trópicos, de 1978, com Vale quanto pesa, de 1982, que melhor podemos compreender as interfaces disciplinares de que tira proveito Santiago, seja para discutir noções que restringem a comparação entre literaturas, seja para argumentar sobre aquelas que permitem compreender a contribuição das variadas formas de manifestação de margem. Quanto à História, ficamos sabendo que a afirmação dos 
dados duplicadores nada mais fez do que realçar a glória do percurso da cultura dominante e o rebaixamento da cultura dominada. O inverso disso, que diria do estereotipado elogio ao que era somente nosso, também não levaria a uma reflexão produtiva, já que a defesa de um pensamento destituído de qualquer traço alienígena constituiria puro "devaneio verdeamarelo" (SANTIAGO, 1982, p. 20). Se a história universal relata nossos acontecimentos por pressupostos que leem aqui o que é para ser lido lá, ela só faz apagar o que pensa construir no interior do truncado discurso que produz. Por outro lado, embora a Antropologia se volte para a análise da cultura destituída de a priori, ela ainda não consolida a "explicação" de nossa "constituição", tanto por falar do "ser enquanto destruição", quanto por ocupar, para a História, um lugar de mera "ficção". Foi preciso entender essas circunstâncias das variações disciplinares para que Silviano pensasse na função do intelectual estabelecido em países colonizados: "o intelectual brasileiro, no século XX, vive o drama de ter de recorrer a um discurso histórico, que o explica, mas que o destruiu, e a um discurso antropológico, que não mais o explica, mas que fala do seu ser enquanto destruição" (SANTIAGO, 1982, p. 17).

No ensaio "Apesar de dependente, universal” (SANTIAGO, 1982, p. 13-24), Silviano chama atenção para um dado que considera problemático quanto aos limites dos pressupostos da dialética do "materialismo histórico" e da Antropologia para dar conta da inserção do intelectual dos países colonizados. Optamos por trazê-lo para este espaço por uma espécie de paráfrase, já que, por considerarmos a questão da maior relevância para aqueles que se voltam para o estudo de suas reflexões, nossa ideia foi ficar o mais próximo possível do que pensou. Escreve ele que, na configuração "ambivalente do seu [intelectual] ser cultural reside o drama ético do intelectual brasileiro em face de todas as minorias da América Latina”. Segundo Silviano, a compreensão do intelectual dessas minorias pelo materialismo histórico tem de passar pela integração total e definitiva delas ao processo de ocidentalização do mundo. Isso por um lado; por outro, a compreensão dessas minorias pelo pensamento antropológico tem de questionar essa integração histórica, para que não continuem a viver uma "ficção" imposta como determinante do seu passado e do seu desaparecimento futuro. Difícil é o pacto entre o homem latinoamericano e a História ocidental, a não ser que se caia em certas determinações de cunho desenvolvimentista, onde se afigura como capital a práxis ideológica do progresso (SANTIAGO, 1982, p. 18).

Como então nos explicar e nos constituir?, perguntamo-nos junto a Silviano Santiago. Responde o autor que nenhum campo disciplinar está autorizado integralmente nesta tarefa. Se esta é a conclusão a que chega, seus ensaios nos conduzem a outro possível entendimento: o entendimento que diz da importância que assumiu a Literatura comparada através de sua 
matriz, a teoria que condensa os pressupostos pelos quais reflete sobre relações culturais. A proposta de analisar as sociedades colonizadas pelo conceito de "entre-lugar" resulta, sem dúvida, de um questionamento decisivo de sua função como intelectual, sendo que, neste diagnóstico, percebo rastros que a Desconstrução foi capaz de fincar. Aquilo que Silviano espera da Antropologia - o questionamento das minorias em sua "integração ao processo de ocidentalização" - significa, na verdade, o que ele próprio faz: questiona a "integração histórica" por pressupostos antropológicos, sem cair na ilusão de que as minorias existiriam fora de um processo de ocidentalização do mundo. Integra-as pelo conceito de diferença, o que retira qualquer "ficção" criada pela História.

Compreendemos que, de fato, o discurso latino-americano, por resistir pertencer exclusivamente a um campo - nem "materialismo histórico", nem "pacto com a História ocidental", nem "ufanismo" nacionalista - implica um entendimento que atenda à particularidade de uma condição específica. Nasce de um "entre-lugar" e este local significa criar pela assimilação da riqueza do repertório que faz emergir uma outra forma de expressão, a forma possível somente na condição do "entre", dos dados em diferença manifestos na simultaneidade da semelhança, mas da semelhança antropofágica que rearticula as referências artísticas. Se assim é o discurso latino-americano, cabe também ao intelectual perceber o significado de sua ocupação neste "entre-lugar", a fim de que a interpretação das condições das culturas e das literaturas de "margem" revista-se de leitura que de fato atenda às exigências de estudos comparatistas.

Nesse sentido, fica claro, por exemplo, por que Silviano Santiago refere-se à "antropofagia" de Oswald de Andrade como um "antídoto" do modernismo ao "enciclopedismo europeucêntrico", assinalando a vontade desse nosso escritor em “incorporar, criativamente, a sua produção dentro de um movimento universal" (SANTIAGO, 1982, p. 21). Quando nos reportamos ao movimento de 22, percebemos que a literatura de Oswald de Andrade expressa, de fato, o estatuto do escritor de uma época em que seu país não era nem economicamente desenvolvido, nem se via imerso na radical incapacidade de vislumbrar as novas técnicas europeias. O compromisso de Oswald com a vanguarda modernista coloca-o no paradoxo de ser um soldado subalterno na tropa do progresso europeu $\mathrm{e}$, ao mesmo tempo, pertencer à avant-garde nacional. Isto significa ocupar um lugar do qual ora se pode ver quem está à frente - o avanço estrangeiro -, ora voltar-se para a direção oposta e ver o passado que ficou para trás. Essa condição de "entre-lugar", propulsora de perguntas do tipo 'fico com minhas raízes ou me entrego à modernidade da poesia estrangeira?', resulta em resposta, já dada pela literatura de Oswald de Andrade, e que poderia 
ser traduzida assim: 'não fico nem com uma, nem com outra; vivo a experiência das duas'. A forma coloquial aqui imaginada é um modo de traduzir o movimento do discurso latinoamericano se apropria do outro para transgredi-lo. Em outras palavras, um modo de tratar do que foi dito oralmente por Silviano em sala de aula e, em termos teóricos, expandido em suas publicações. O resultado é a instauração de uma tensão entre possibilidades. Neste sentido, ao intérprete não escapou nem o "primeiro texto", nem a "rearticulação" decorrente da "desarticulação":

O texto se organiza a partir de uma meditação silenciosa e traiçoeira sobre o primeiro texto, e o leitor, transformado em autor, tenta surpreender o modelo original nas suas limitações, nas suas fraquezas, nas suas lacunas, desarticula-o e rearticula de acordo com suas intenções, seguindo sua própria direção ideológica, sua visão do tema, apresentado de início pelo original (SANTIAGO, 1978, p. 22).

Esse complexo movimento que desemboca em "rearticulação" é recorrente na obra de Oswald como um todo, embora duas de suas manifestações sejam modelares para ilustrar a maneira pela qual o escritor da vanguarda de 22 absorveu antropofagicamente o "dejà-dut", conforme escreveu Foucault, ou o "já-escrito", como Silviano preferiu traduzir (SANTIAGO, 1978, p. 22). Uma delas diz respeito aos fragmentos que fazem parte da coleção de poemas Pau Brasil. Os trechos da Carta de Pero Vaz, transpostos para as páginas do poeta do século XX, acabam por fundar uma estética - a estética do modernismo de Oswald -, pela estratégia de penetrar primeiramente no que é nosso (a Carta), retirá-lo de sua procedência e reorganizálo sob a condição de outra geografia temporal-discursiva (o Poema). O olhar para o passado e o compromisso com a vanguarda aparecem através das estratégias de justaposição e de ressignificação dos dados de uma história que já havia sido contada. A ausência de cerimônia na nova assinatura de Oswald no "já-dito" - "por ocasião da descoberta do Brasil” - em Pau Brasil remete para a "descontinuidade". Melhor do que isso, contudo, foi a bela criação artística que daí resultou ao deslocar temporária e espacialmente o texto do colonizador:

Pau-Brasil, primeira coleção de poemas de Oswald de Andrade, serve para espicaçar os historiadores que são servos obedientes da cronologia e os que são defensores de princípios históricos normativos. Para dramatizar a situação lacunar, resolve bagunçar o coreto do tempo e da história ocidental. Faz ele questão de assinalar, desde o pórtico do livro, que aqueles poemas escritos em 1924 o foram "por ocasião da descoberta do Brasil" (SANTIAGO, 1992, p. 166). 
É esse tipo de estética antropofágica que aparece também na "Canção de exílio", de Oswald de Andrade. Além da apropriação literal do primeiro título, desarticulando-o pela lacuna instaurada entre vanguarda e romantismo, o poeta rearticula-o quando introduz, nessa semelhança, o dado da diferença, que é a palavra "palmares" do primeiro verso modernista ("Minha terra tem palmares"). Diferente das leituras mais conhecidas desse fragmento pela paródia do modernismo, a interpretação pode tomar outro rumo: apresentá-lo como pastiche e dele fazer uma força vanguardista. Remeteria então tanto para a referência do "já dito" por Gonçalves Dias ("Minha terra tem palmeiras"), a metáfora de nosso passado enaltecedor da natureza, quanto para "palmares", a diferença resultante da estética antropofágica, ao dizer que também fizemos rebelião libertadora. Ao invés do sentido único, aquele que subverte o significado do ufanismo romântico pela paródia, a interpretação diria das forças do nacional expressas na superfície dos significantes: somos "palmeiras" e somos "palmares"; somos ufanistas e somos revolucionários; somos românticos e somos modernistas.

As interpretações desses dois momentos na literatura de Oswald - Pau Brasil e "Canção do exílio" - revelam, por fim, que, junto à absorção que sua poesia faz do cânone, convive uma outra espécie de antropofagia, desta vez, a antropofagia teórica de Silviano em relação ao pharmakon de Derrida e à "descontinuidade" de Foucault. Se através de sua matriz resgatamos a beleza de Pau Brasil pela interferência da "descontinuidade"; se na "Canção do exílio", não se apaga do texto nem o significado da tradição nem o novo da vanguarda; se é no lugar paradoxal que a literatura da cultura dominada melhor revela suas potencialidades estéticas, isso só pôde ocorrer porque coube ao crítico Silviano Santiago apropriar-se antropofagicamente das noções dos filósofos franceses, rearticulando seus conceitos em outro campo do saber, de modo que sua Teoria da literatura comparada fosse ao encontro do que a própria obra provocava. Em compasso com os filósofos da Desconstrução, a interpretação do “entre-lugar" abriu as portas para que nosso intelectual, na inevitável condição de leitor de uma cultura diferente da europeia, se posicionasse conceitualmente, de modo a fazer emergir a riqueza, a complexidade e o paradoxo da condição de nossa literatura e daquele que fala desse lugar em que ela é produzida.

\section{Referências bibliográficas:}

CORTESÃO, Jaime. A carta de Pero Vaz de Caminha. São Paulo: Livros de Portugal, 1943. 
CUNHA, Eneida Leal. Leituras da dependência cultural. In: __ ; Wander Melo Miranda (Orgs.). Navegar é preciso, viver. Escritos para Silviano Santiago. Belo Horizonte: EdUFMG; Salvador: EdUFBA; Niterói, RJ: EdUFF,1997, p.126-139.

DERRIDA, Jacques. Gramatologia. São Paulo: Perspectiva, 1973. . A escritura e a diferença. São Paulo: Perspectiva, 1971.

DUQUE-ESTRADA, Paulo César (Org.) Às margens: a propósito de Jacques Derrida. São Paulo: Loyola, 2002.

FOUCAULT, Michel. A arqueologia do saber. Petrópolis, RJ: Vozes, 1972. As palavras e as coisas. São Paulo: Martins, 1966. A ordem do discurso São Paulo: Loyola, 2001. Nietzsche, Freud e Marx. Teatro Filosófico. Porto: Publicações Anagrama, s/d.

LIMA, Rachel Esteves. A crítica cultural na Universidade. In: SOUZA, Eneida Maria de; MIRANDA, Wander Melo (Orgs.). Navegar é preciso, viver. Escritos para Silviano Santiago. Belo Horizonte: EdUFMG; Salvador: EdUFBA; Niterói, RJ: EdUFF,1997, p.170-186.

NÓBREGA, Pe. Manuel da. Carta a El Rei D. João. 1552. In: Cartas jesuíticas e cartas do Brasil: 1549-1560. Rio de Janeiro: Oficina Indústria Gráfica, 1931.

SANTIAGO, Silviano. Uma literatura nos trópicos. São Paulo: Perspectiva, 1978. (Supervisão). Glossário de Derrida. Rio de Janeiro: Francisco Alves, 1976.

Apesar de dependente, universal. In: Vale quanto pesa: ensaios sobre questões político-culturais. Rio de Janeiro: Paz e Terra, 1982, p. 13-24.

Nas malhas da letra. São Paulo: Companhia das Letras, 1989.

. Oswald de Andrade ou O elogio da tolerância racial. In: Revista Crítica das Ciências Sociais, Universidade Federal Fluminense, jun. 1992, n.35, p.165-175.

SANTOS, Roberto Corrêa dos. Para uma teoria da interpretação: semiologia, literatura e interdisciplinaridade. Rio de Janeiro: Forense Universitária, 1989.

Clarice Lispector. São Paulo: Atual, 1986.

SCHWARZ, Roberto et al. Tradição e contradição. Rio de Janeiro: Zahar; Funarte, 1987.

SOUZA, Roberto Acízelo de. Teoria da literatura. São Paulo: Ática, 1986.

VIEIRA, Antonio. Sermão do Espírito Santo. In: Sermões. São Paulo: Cultrix; Brasília, DF: MEC, 1975. 
Deconstructionist philosophical thinking and Theory of Interpretation

\begin{abstract}
This article is a reflection on Michel Foucault's and Jacques Derrida's concept of Deconstruction and aims at describing how their ideas were comprehended by Silviano Santiago, when this author investigated Brazilian literature and culture, during the seventies and eighties. The concepts created by Silviano Santiago are able to reveal another interpretative perspective, as he criticizes Western metaphysical theories.
\end{abstract}

Key words: Deconstruction. Interpretation. Brazilian culture and literature. 